\title{
Factors Affecting the Supply of "Missing Middle" Housing Types in Walkable Urban Core Neighborhoods
}

By

Shrimatee Ojah Maharaj, University of South Florida

$\mathrm{H}$ ousing preferences are changing. According to Koebel, Lang, and Danielsen (2004), Kolson (2016), Myers and Ryu (2008), Shaver (2017), and Woo (2016), the largest demographic, the millennials, prefer low- to mid-rise housing units in the walkable urban core areas. These areas have access to cultural activities, entertainment, restaurants, shopping, and other amenities such as parks. The retiring baby boomers (Table 1), who are downsizing from their single-family suburban homes, are seeking the same housing types and amenities. As suggested by Parolek (CNU, 2015), the Missing Middle Housing types are one possible solution to help meet the demand. However, the demand is greater than the supply (Koebel et al., 2004; Kolson, 2016; Myers \& Ryu, 2008; Shaver, 2017).

This review discusses the factors that affect the supply of MMH types. It reveals that although these housing types once existed in the urban core, attempts to reintroduce them met with opposition from several stakeholders. Additional factors that hurt the supply of MMH types include: land use and zoning regulations, a lack of developer interest to develop these units, and a lack of developer financing (Doherty, 2017).

Keywords: Missing middle housing, millennials, baby boomers, traditional, neo-traditional neighborhoods, diversity of housing types, walkability, perception and design, perceived-density.

Copyright @ 2020, Shrimatee Ojah Maharaj. This article is published under a Creative Commons BY-NC license. Permission is granted to copy and distribute this article for non-commercial purposes, in both printed and electronic formats 


\section{Introduction}

This literature review aims to investigate the factors that affect the supply of a variety of low-to mid-rise housing types in the walkable urban core neighborhoods to help meet the housing demand in urban core/central city areas.

The Missing Middle Housing (MMH) types refer to housing that ranges between multi-story units and single-family unit layout, as seen in many cities (Figure 1). The term "Missing Middle Housing types" was coined by Parolek in 2010 and describes the housing types that existed in the urban core in the early $20^{\text {th }}$ century (Opticos Design Inc., 2018). As seen in Figures 1-3, they include:

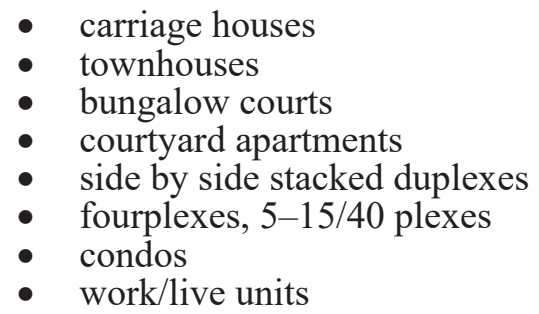

Although MMH is a contemporary term, these types of homes were built pre-World War II (WWII) in urban core neighborhoods.

As consumers' housing preferences changed after WWII, the land use and zoning regulations altered to accommodate the preferences for suburban-type neighborhoods (Bach et al., 2007) . Thus, these types of homes were no longer being built (Lucy \& Phillips, 2006; Vision 2020 Delegates, 2002). MMH types were reintroduced as a possible solution in response to the recent demand by millennials and baby boomers for affordable, walkable housing in urban neighborhoods (Burks, 2017; Mich, 2017; Myers \& Ryu, 2008; Parolek, n.d.; Sisson, 2016). According to Parolek, MMH types are characterized by:

- small footprints

- "perceived" low density (or "gentle density")

- compact in design to fit the character of the neighborhood

- well-designed and simple construction

- requiring less off-street parking due to the walkability

- has shared spaces/common areas such as patios. (Bach et al., 2007; Leyden, 2003; Parolek, 2015, n.d.; Shaver, 2017)

Those characteristics of the MMH types lead to benefits such as:

- walkability, due to the grid-like pattern of the street layout, allows for accessibility to services, entertainment, and public transport
- requiring less off-street parking due to the walkability in the neighborhood

- the human scale of the streets and pedestrian activities and amenities such as restaurants, parks, shopping, and libraries in the neighborhood convey a sense of community and lifestyle, which also fits their pocketbook. (Parolek, 2016)

The compact design and density also provide the customer base necessary for public transportation (Cervero, 1996; CNU, 2018; Leyden, 2003; Parolek, 2016), which minimizes the need for off-street parking (Parolek, 2015). These characteristics are the result of a mix of land uses and the grid-like pattern of the street layout. They encourage walkability and provide accessibility to services that are endemic to traditional neighborhoods. These inherent social, health, economic and environmental benefits have been widely studied (Bach et al., 2007; Bergdoll \& Williams, 1990; Greenwald \& Boarnet, 2001; Kitamura, Mokhtarian, \& Laidet, 1997; Leyden, 2003; Lidwell, Holden, \& Butler, 2010; Lovejoy, Handy, \& Mokhtarian, 2010; Ware, 2012; Wells \& Yang, 2008). Although these land uses were regulated out of the urban core neighborhoods, remnants of these housing types still exist. The decrease in the supply of MMH types after WWII contributed to the low supply today. However, attempts to increase the supply with new construction met with opposition and other barriers (Doherty, 2017; Shaver, 2017) such as:

- land use and zoning restrictions

- neighborhood opposition

- lack of developer interest in building these units

- lack of developer financing

- limited land availability

- high land and construction costs

Despite the opposition and barriers, Parolek proposed $\mathrm{MMH}$ types as a possible solution to help meet housing needs because of the potential benefits and appeal of the housing types (CNU, 2015).

In the Tampa Bay area, there are three recent developments that successfully reflect the MMH types. Glencairn Cottages in Dunedin, Hayes Park Village in Oldsmar, and the rehabilitation of "casitas" (one room wide homes) in Ybor City, Tampa have characteristics of MMH types. The "casitas" were built in the $19^{\text {th }}$ and $20^{\text {th }}$ centuries. Homes in this area are currently undergoing renewal (Forward Pinellas, 2017). Glencairn Cottages is adjacent to downtown Dunedin. This adjacency accommodates several benefits of the MMH types, including walkability and amenities. Hayes Park Village in Oldsmar is also located close to amenities such as grocery shopping and a city park. A preliminary informatics review of 

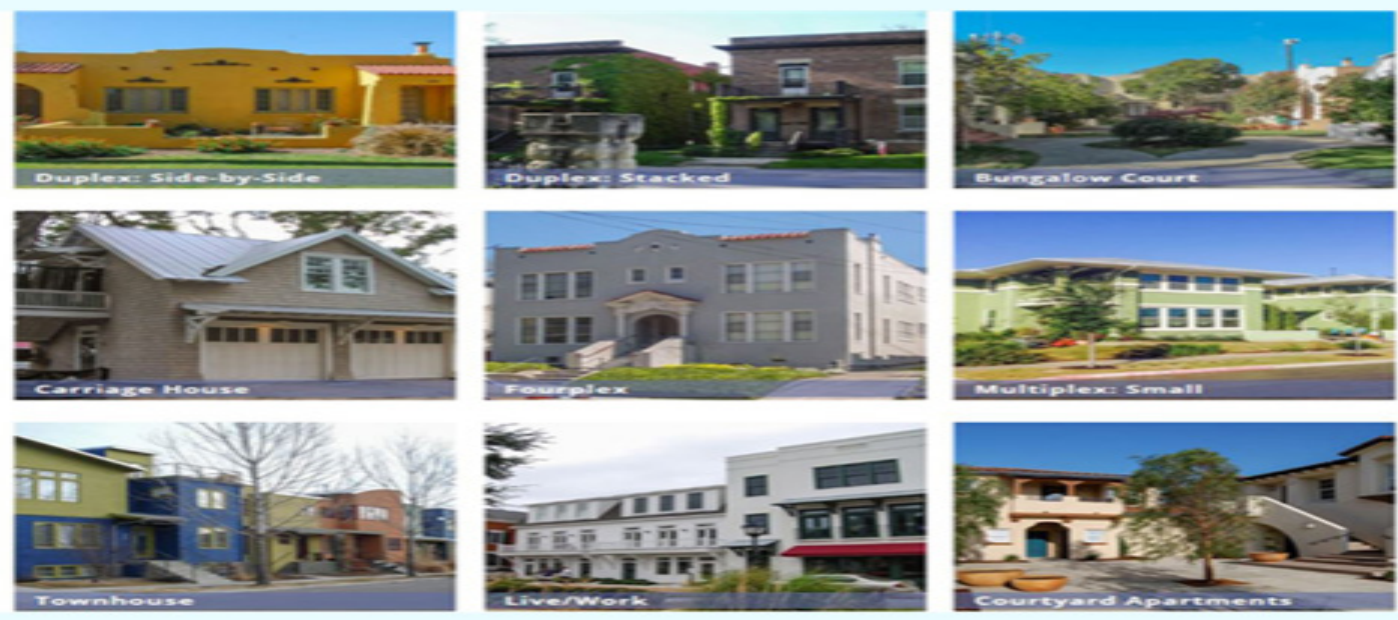

Figure 1. Missing Middle Housing Types

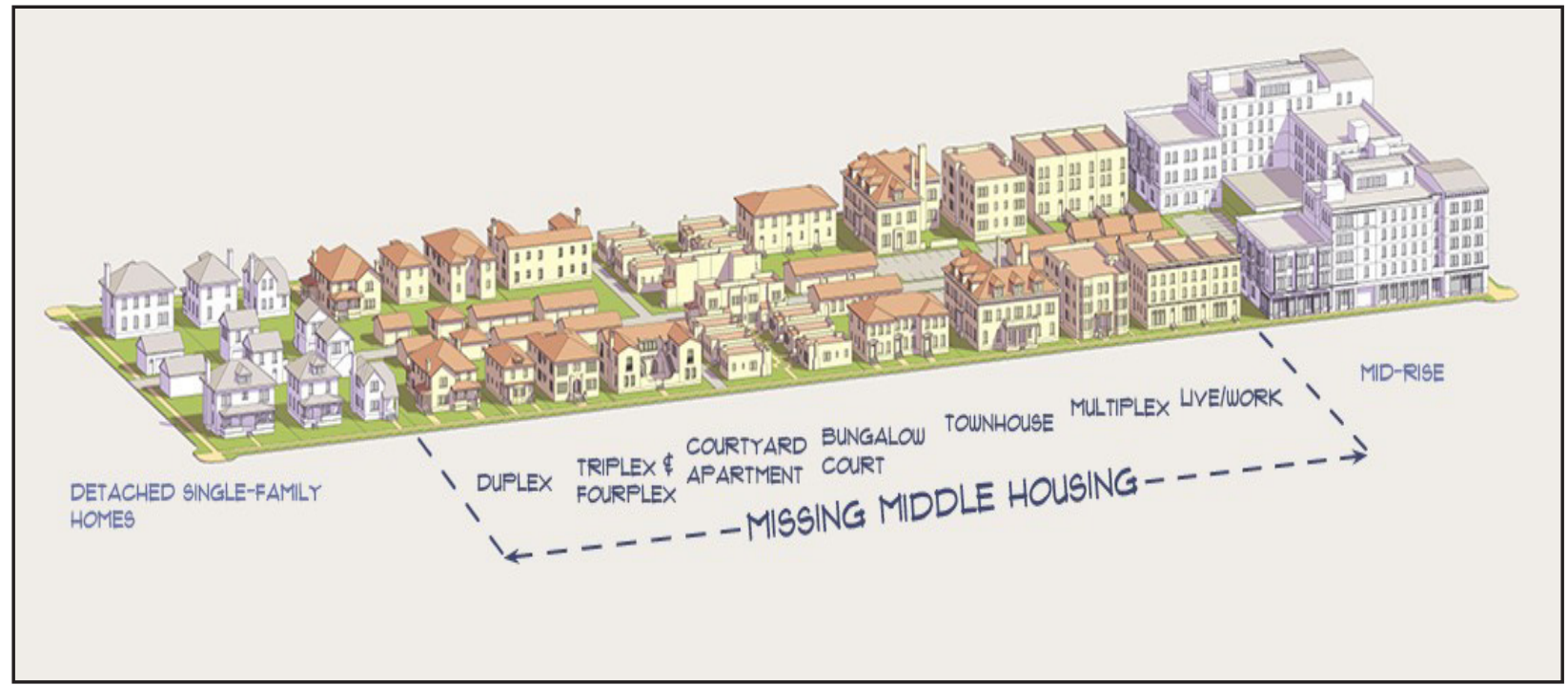

Figure 2. Missing Middle Housing Types (Note. Figures 1 and 2 Adapted from Missing Middle Housing types, Opticos Design Inc. (2018).

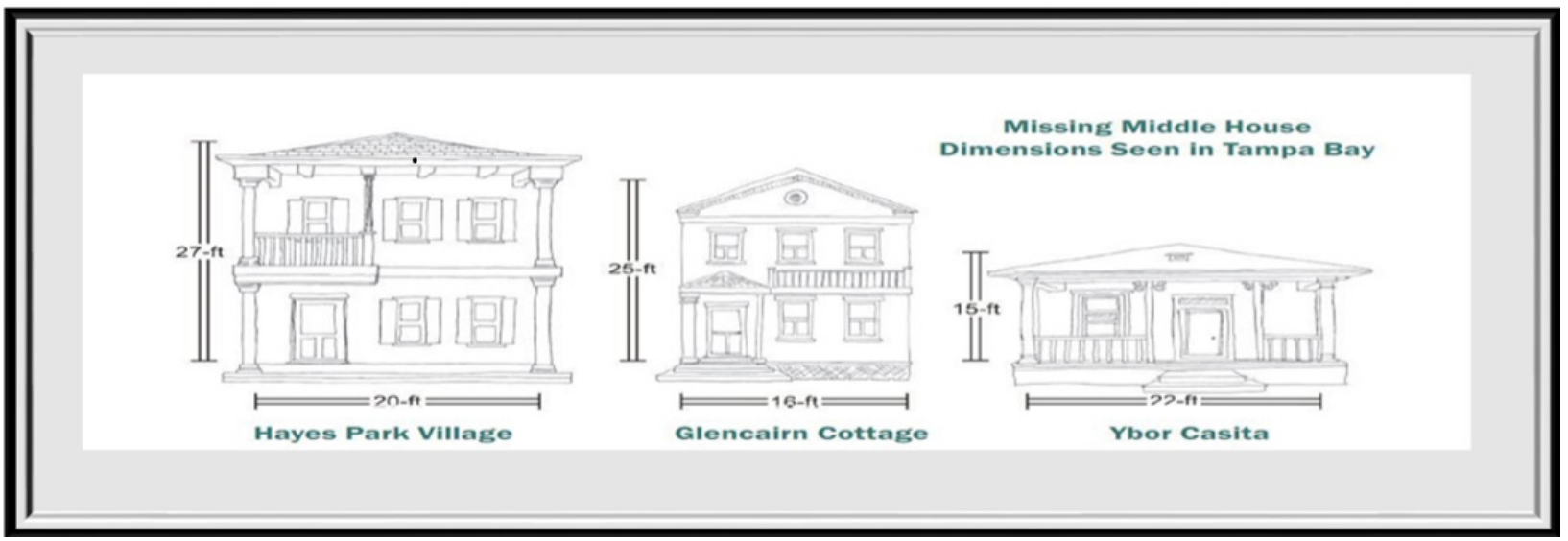

Figure 3. Examples of MMH Types in the Tampa Bay Area. Adapted from Forward Pinellas (2017) 
Table 1: Concepts and Meanings

\begin{tabular}{|c|c|}
\hline Concept & Meaning \\
\hline $\begin{array}{l}\text { Affordable Hous- } \\
\text { ing }\end{array}$ & $\begin{array}{l}\text { There are various ways of determining affordability for an area (Demographia, 2016; } \\
\text { Koebel et al., 2004; Lucy \& Phillips, 2006). Affordable housing in this study is based on } \\
\text { the Area Median Income (AMI), established by the Housing and Urban Development } \\
\text { (HUD) (Koebel et al., 2004). Thirty percent (30\%) of Annual Household Income is on } \\
\text { housing expenses (generally mortgage, insurance, and utilities). In this context, the } \\
\text { housing type addressed is "market rate" or non-subsidized workforce housing. The } \\
\text { Area Median Income for Tampa/St. Petersburg is } \$ 59,800 \text {. }\end{array}$ \\
\hline $\begin{array}{l}\text { Life Cycle Hous- } \\
\text { ing, Stage of Life }\end{array}$ & $\begin{array}{l}\text { Choices in housing that suits the needs based on the stage-of-life of an individual rent- } \\
\text { al for single/couples first time home buyers; small family or townhouse; multi-fami- } \\
\text { ly-smaller units for retirees-age in place; car-free residents. }\end{array}$ \\
\hline $\begin{array}{l}\text { "Step Up" Hous- } \\
\text { ing }\end{array}$ & $\begin{array}{l}\text { Moving from one housing type to another-such as rental to townhouse to sin- } \\
\text { gle-family. }\end{array}$ \\
\hline $\begin{array}{l}\text { Urban Renewal, } \\
\text { regeneration, re- } \\
\text { vitalization }\end{array}$ & $\begin{array}{l}\text { A process by which a dilapidated area is redeveloped. Signs of decline could include } \\
\text { broken sidewalks/roadways, windows, storefronts, overgrown trees, and unkempt/ } \\
\text { abandoned yards and properties. It can also have high crime and poverty. }\end{array}$ \\
\hline $\begin{array}{l}\text { Tradition a } 1 \\
\text { Neighborhoods } \\
\text { (Old tradition- } \\
\text { al, Urban Core } \\
\text { Neighborhoods) }\end{array}$ & $\begin{array}{l}\text { Neighborhoods built before WWII, in the early 1900s. House characteristics were } \\
\text { front porches, rear-parking with access from the alley and built on small lots, medium } \\
\text { density. The neighborhoods were built on grid-like street patterns, with a mix of land } \\
\text { uses encouraging walkability/pedestrian activity. The mix and density provided the } \\
\text { opportunity for live/work situations and the customer base for economic activity and } \\
\text { transit. }\end{array}$ \\
\hline $\begin{array}{l}\text { Suburban Neigh- } \\
\text { borhoods }\end{array}$ & $\begin{array}{l}\text { Neighborhoods built after WWII. They are built away from the urban core and are } \\
\text { characterisedby separated land uses, large lots, larger single-family homes, parking } \\
\text { to the front, and the streets terminated with cul-de-sacs. Referred to as Planned Unit } \\
\text { Developments (PUDs), they were built away from the jobs and community and were } \\
\text { auto-dependent (Wells \& Yang, 2008). }\end{array}$ \\
\hline Urban Sprawl & $\begin{array}{l}\text { The result of the suburban neighborhoods. The spread-out of neighborhoods from } \\
\text { the urban core. Auto-dependent, large roadway systems, and increase infrastructure. } \\
\text { It reflects the negative aspects of suburbanism, such as long commute, traffic conges- } \\
\text { tion, air pollution, and health issues due to the lack of walkability (Zeng, Liu, Liu, \& } \\
\text { Qiu, 2014). }\end{array}$ \\
\hline $\begin{array}{l}\text { New Urbanism, } \\
\text { Neo-Traditional } \\
\text { Neighborhoods }\end{array}$ & $\begin{array}{l}\text { Neighborhoods built after suburban neighborhoods (mid-to-late 80s) using the con- } \\
\text { cept of the traditional neighborhoods. Diverse housing types of various low- rise den- } \\
\text { sities to recapture the traditional neighborhoods with Traditional Neighborhood De- } \\
\text { signs to correct the failings of PUDs (CNU, 2018). }\end{array}$ \\
\hline Walkability & $\begin{array}{l}\text { The prerequisites for walkability are the mixed uses for living, work, shop, school, and } \\
\text { play without having to drive. A mix of uses found in older cities where offices and } \\
\text { apartments exist over retail stores and corner shops located in residential neighbor- } \\
\text { hoods (CNU, 2018). }\end{array}$ \\
\hline Barriers & Factors that prevent or inhibit. \\
\hline Dodd-Frank & $\begin{array}{l}\text { Wall Street Reform and Consumer Protection Act. In the U.S federal law for the regu- } \\
\text { lation of the financial industry by the government. }\end{array}$ \\
\hline Cohorts & $\begin{array}{l}\text { Cohort Effect unique to that cohort may cross over with impact in the future, the mil- } \\
\text { lennials are the most diverse adult generation }(57 \%) \text {, non-Hispanic whites (61\% Gen } \\
\text { X), } 72 \% \text { baby boomers and } 78 \% \text { silent (Pew Research Center, 2015). }\end{array}$ \\
\hline Millennial & $\begin{array}{l}\text { Individuals born between 1982-1997/2001 (Pew Research Center, 2015, based on } \\
2014 \text { data). }\end{array}$ \\
\hline Baby Boomer & $\begin{array}{l}\text { uals born between WWII (1943-1960) a period when there was a significant } \\
\text { births (Pew Research Center, 2015, based on } 2014 \text { data). }\end{array}$ \\
\hline
\end{tabular}




\section{Methodology}

Keywords: Affordable housing, missing middle housing, millennials, baby boomers, traditional and neo-traditional neighborhoods, diversity of housing types, walkability, marketability, density, and design (of housing), perception and design and perceived density (of housing), urban sprawl.

Novelty of the Subject Matter: A New Name

Missing Middle Housing ( $\mathrm{MMH}$ ) is a new name given to low-rise diverse housing types in traditional neighborhoods. Thus, academic literature on MMH types is limited. However, research on traditional and suburban neighborhoods was widely conducted. The benefits ascribed to MMH by Parolek (n.d.) are based on those studies. Consequently, searches of keywords such as traditional and suburban neighborhoods, produced thousands of articles. The most highly cited articles were selected from the first one to two pages of articles generated from the search. These articles were further screened by reviewing the abstract for relevance to the subject.

Databases

Databases searched were Find IT, Google, and Google Scholar. Specific search words were: "the missing middle housing types," "diversity of housing types," "affordable housing," and "traditional and suburban neighborhoods," "millennials," and "boomers." Additionally, preference was given to empirical studiesarticles from peer-reviewed journals, such as the Journal of American Planning Association. References from pertinent academic articles were helpful resources. Several MMH type articles were current blogs, magazines, newspaper articles, and practitioner sites such as the Congress of New Urbanism, Urban Land Institute, and Forbes magazine. One master's thesis on MMH types in the Greater Boston area was found (Mich, 2017). Other local studies cited were obtained through conversations with local urban planners and thought leaders.

the three developments and a discussion with one of the developers (Carl Kraves, Glencairn Cottages) revealed that practitioners and policymakers collaborated with developers who had a specific affinity for MMH types (Burks 2017). Burks (2017) also indicated the developers specialized in small developments and were inspired by the housing types that existed in older neighborhoods.

Table 1 contains a glossary of key terms, concepts and meanings.

\section{Literature Summary}

The following tables are a summary of the findings of the literature reviewed for this study. They are arranged into five tables. Table 2: Affordable Housing and Design; Table 3: Benefits of Diverse Affordable Housing Types; Table 4: Millennials Housing Preferences; Table 5: Barriers to MMH Types; and Table 6: The Tampa Bay Area: Missing Middle Housing Initiatives.

\section{Discussion}

\section{Demand}

There is a high demand for MMH types (Myers \& Ryu, 2008; Shaver, 2017; Woo, 2016). A new generation of college graduates, young professionals, and skilled workers-the millennials-are seeking $\mathrm{MHH}$ and have overtaken the boomers in population-75.4 million vs. 74.9 million (Fry, 2018; Fry et al., 2018). However, the boomers are retiring, down- sizing from their large single-family homes in the suburbs and are also seeking MMH types (Abrahms, 2016; Myers \& Ryu, 2008). In past generations, the succession in the homeownership (step-up ladder) occurred. When younger generations were coupling up or single and sought homeownership, they would occupy the void created by the Boomers in the suburbs who downsized (Myers \& Ryu, 2008). However, this succession was jolted by millennials' stage in life delays for marriage and homeownership. Additionally, this difference was marked by the millennials' differences in housing preferences. These housing preferences include housing that is accessible to amenities, has smaller functional spaces, located in walkable areas to suit the lifestyle they desire and free up more time to spend on activities they prefer (Fry, 2018; Fry et al., 2018; Sisson, 2016). Additionally, their lack of economic mobility, high student loan debts, rising rents, and job insecurity prevent them from homeownership of their choice (McKinney, 2016; Woo, 2016).

\section{Low Supply in The Housing Market}

$\mathrm{MMH}$ land uses were regulated out of the urban core neighborhoods, but remnants of the housing types still exist (Lucy \& Phillips, 2006; Parolek, 2015; Vision 2020 Delegates, 2002). As of August 2018, the current month's supply of inventory nationally, which is an estimate of the number of months it will take to deplete the current inventory based on recent sales, is 4.3 months. In the Tampa Bay area, which 
Table 2: Affordable Housing and Design

Source

Anenberg, E., \& Kung, E. (2018) Can more housing supply solve the affordability crisis? Evidence from a neighborhood choice model.

Tiesdell, S. (2004) Integrating affordable housing within market-rate developments: The design dimension.
Koebel, C. T., Lang, R. E., \& Danielsen, K. A. (2004) Community acceptance of affordable housing.
Contribution/Findings

Based on the model design on 2014 ACS (American Community Service Data). The survey investigated whether new housing supply can improve housing affordability. Small reductions alone, in factors that affect supply, will not reduce rents noticeably. Instead, the study found that rent is more closely related to the number of amenities in a neighborhood.

The design aspect of the housing policies in England was studied. In the early 2000 s, British planning required mixed housing types. Based on the size, part of the development must be integrated with diverse communities. The main design aspects are the layout and design, which were used for the design strategies and outcomes with affordable housing. The study revealed, high-density housing was perceived as indicating poverty, deteriorated conditions, and poor management.

A report to the National Association of Realtors (National Center for Real Estate Research) covered the various definitions of affordable housing (p. 10). In 2003, the study determined there is insufficient land supply zoned at densities to support affordable housing (p. 3). The study revealed affordable housing elicits fear in neighborhood residents. The fear or property devaluation, negative government and anti-poor feelings, prejudices, and segregation (p. 61). The survey results from this report showed support for affordable housing was high (80\%) if it fits the neighborhood and is well-designed and maintained (Chicago). Further research needed. includes Hillsborough and Pinellas Counties, the inventory is at 3.6 months and 2.6, months, respectively. This rate of supply indicates it is a seller's market where inventory cannot keep up with the demand (National Association of Realtors, 2018).

\section{Benefits}

The benefits of MMH types are walkability and accessibility to services and amenities such as parks, and cultural activities, which are attractive to a range of age groups, particularly the millennials and boomers (Parolek, n.d.). As proposed by Parolek (n.d.), MMH types are characteristic of housing in walkable areas, with small footprints, "perceived" low density (or "gentle density"), well-designed and simple construction. They require less off-street parking due to the walkability in the neighborhood. The compactness of the design, the human scale of the streets, and pedestrian activities and amenities such as restaurants, parks, shopping, and libraries in the neighborhood convey a sense of community. These benefits are attractive to millennials and boomers who are looking for such a lifestyle that also fits their pocketbook (Bach et al., 2007; Leyden, 2003; Parolek, 2015; Shaver, 2017). The compactness in density and design also provides the customer base necessary for public transportation (Cervero, 1996; CNU, 2018; Leyden, 2003; Parolek, 2016), which minimizes the need for off-street parking ( $\mathrm{Pa}-$ rolek, 2015).

\section{Traditional Neighborhoods, MMH Types}

MMH characteristics reflect a mix of land uses, unique designs of the homes, the grid-like pattern of the street layout, which encourages walkability, and accessibility to services prevalent in traditional neighborhoods (Bach et al., 2007; Bergdoll \& Williams, 1990; Greenwald \& Boarnet, 2001; Kitamura et al., 1997; Leyden, 2003; Lidwell et al., 2010; Lovejoy et al., 2010; Ware, 2012; Wells \& Yang, 2008). However, due to changes in housing preferences in the mid- $20^{\text {th }}$ century, these land uses were regulated out of the urban core neighborhoods. Today, remnants of traditional neighborhood housing types still exist and are in high demand (Lucy \& Phillips, 2006; Parolek, 2015; Vision 2020 Delegates, 2002).

\section{Overcoming the Challenges}

With a lack of supply of MMH types in the urban core, millennials are even looking at the suburbs for $\mathrm{MMH}$ types as first-time home buyers. However, no one is building the product they want (Leyden, 2003; Sisson, 2016). MMH types exist as remnants in the urban core from the early $20^{\text {th }}$ century due to regulation changes to meet the housing preferences in 
Table 3: Benefits of Diverse Affordable Housing Types

\begin{tabular}{|c|c|}
\hline Source & Contribution/Findings \\
\hline $\begin{array}{l}\text { Bergdoll, J. R., \& Williams, R. W. } \\
\text { (1990) Density perception on residen- } \\
\text { tial streets. }\end{array}$ & $\begin{array}{l}\text { A study based on people's perceptions of density on urban } \\
\text { residential streets. Based on visual features, three streets in } \\
\text { San Francisco were evaluated. The optical elements such as } \\
\text { colors, materials, patterns and different unique features of } \\
\text { forms. The study associates three aspects of design linked } \\
\text { with low density: 1) high articulation, 2) segmented facades } \\
\text { to appear smaller, and 3) make buildings appear like a house } \\
\text { (p. 15). }\end{array}$ \\
\hline $\begin{array}{l}\text { Walk Score Professional (https://www. } \\
\text { walkscore.com) }\end{array}$ & $\begin{array}{l}\text { A website that provides information on neighborhood walk- } \\
\text { ability, amenities, transportation options for commuting, } \\
\text { lifestyle, crime, ambiance. Build Apps, Data and Analysis }\end{array}$ \\
\hline $\begin{array}{l}\text { Leyden, K. M. (2003) Social capital } \\
\text { and the built environment: The im- } \\
\text { portance of walkable neighborhoods. }\end{array}$ & $\begin{array}{l}\text { - The study highlights the importance such as social capital } \\
\text { of traditional neighborhoods on a community. Social capital } \\
\text { is the social networks and interactions that elicit trust and } \\
\text { reciprocity among citizens (Leyden 2003). } \\
\text { The study examined the relationship between neighborhood } \\
\text { design and social capital. Factors related decline, long com- } \\
\text { mutes, lack of socialization linked to sub-urbanization (p. } \\
\text { 1546). Social capital is the social networks and interactions } \\
\text { that inspire trust and reciprocity among citizens (p. 1546). } \\
\text { Social Capital has also been linked to enhanced econom- } \\
\text { ic development, prevention of crime promotes trust and a } \\
\text { feeling of safety. Traditional or "Complete Neighborhoods" } \\
\text { found in older cities, neighborhoods and rural areas have } \\
\text { mixed uses and walkable streets encouraging daily activ- } \\
\text { ities, grocery shopping, other services, coffee shops, local } \\
\text { bars, houses of worship. Social Capital and the Linkage of } \\
\text { the community to MMH types }\end{array}$ \\
\hline $\begin{array}{l}\text { Bach, A., Gupta, P. K., Haughey, R., } \\
\text { Kelly, G., Pawlukiewicz, M., \& Pitch- } \\
\text { ford, M. (2007) Ten principles for de- } \\
\text { veloping affordable housing. }\end{array}$ & $\begin{array}{l}\text { The study provides guidelines for developing and working } \\
\text { with a community on affordable housing. It states opposi- } \\
\text { tion to affordable housing is based on misperceptions of the } \\
\text { potential clients and on the appearance and type of struc- } \\
\text { tures. Suggestions to educate the public to mitigate negative } \\
\text { perceptions on the actual residents who may be elderly } \\
\text { couples on a fixed income, working families, professionals, } \\
\text { college graduates' parents or children of residents of the } \\
\text { community. Various housing types create a lively city, and } \\
\text { most importantly, a sustainable community. That is different } \\
\text { housing types that can support socio-economic and demo- } \\
\text { graphic differences (p. 3). The study cites adjacency to work } \\
\text { is crucial to an area's economic well-being (p. 4). Suburbia, } \\
\text { in contrast, is socio-economically homogeneous, and auto- } \\
\text { mobile-dependent, and is bent on privacy. }\end{array}$ \\
\hline
\end{tabular}

the mid- $20^{\text {th }}$ century. Developers are not going into the urban core to build these units and help meet the demand (Burks, 2017; Shaver, 2017). Because the land use and zoning regulations were changed in the mid-late $20^{\text {th }}$ century to accommodate the suburban -type housing preferences then, efforts to fully bring MMH types in the urban core would require regulatory changes at the local government level. This requirement is inevitable but it is a time-consuming process (Mich, 2017). In areas of high land and con- struction costs, few developers are willing to pursue the work due to market forces and regulatory challenges. Shaver (2017) demonstrates a developer's willingness to work through the high cost of land and regulatory barriers. The article suggested local governments double the zoning allowances and relax parking regulations. Developers would reduce the bedroom size, and create common spaces such as patios to make projects more profitable for them and affordable for the residents (Mich, 2017; Shaver, 
Table 4: Millennials Housing Preferences

\begin{tabular}{|c|c|}
\hline Source & Contribution/Findings \\
\hline $\begin{array}{l}\text { Fry, R. (2018) Millennials projected to } \\
\text { overtake Baby Boomers as America’s } \\
\text { largest generation. }\end{array}$ & $\begin{array}{l}\text { - Descriptor population of the various generations with an } \\
\text { emphasis on the boomers and millennials indicating the } \\
\text { millennials has overtaken the boomers ( } 75.4 \text { million vs. } \\
74.9 \text { million). }\end{array}$ \\
\hline $\begin{array}{l}\text { Myers, D., \& Ryu, S. (2008) Aging baby } \\
\text { boomers and the generational housing } \\
\text { bubble: Foresight and mitigation of an } \\
\text { epic transition. }\end{array}$ & $\begin{array}{l}\text { - In 2008, Myers et al. studied what might happen when } \\
\text { boomers begin to sell off their high-priced homes to a small } \\
\text { and less affluent generation. This generation (approximately } \\
78 \text { million), has driven the demand for housing since } 1970 \text {. } \\
\text { The authors concluded: } \\
\text { 85\% of home sales were by existing homes owners. Se- } \\
\text { niors (aging population). The authors predicted the ratio of } \\
\text { seniors to working-age residents would increase by } 67 \% \\
\text { over the next two decades, thus ending the generational } \\
\text { housing bubble, and younger generations will not be able to } \\
\text { afford housing. Authors proposed planners could mitigate } \\
\text { the effects of this projection. The authors predicted the re- } \\
\text { tirement of boomers could be the end of suburbia planning } \\
\text { with declining demand for low-density housing and the rise } \\
\text { of more compact development with a call for planners to } \\
\text { use new strategies and market and keep boomers. Question? } \\
\text { Did this occur? The authors predicted a diminishing of the } \\
\text { demand for low-density housing and a focus on compact } \\
\text { development. }\end{array}$ \\
\hline $\begin{array}{l}\text { Abrahms, S. (2016) } 5 \text { Questions about } \\
\text { the 'Missing middle housing: AARP } \\
\text { Livable Communities, Housing. }\end{array}$ & $\begin{array}{l}\text { Interview with Daniel Parolek. Provided insights into the } \\
\text { housing types, definition, applicability/use, and the future } \\
\text { of housing needs, the role of developers and policymakers } \\
\text { in these housing types. Parolek stated what the young want, } \\
\text { the baby boomer generation needs. Less auto dependence } \\
\text { and to be part of a connected community. He emphasized } \\
\text { the importance of walkability. Missing Middle Housing } \\
\text { Types tend to be in communities that are age-diverse. }\end{array}$ \\
\hline $\begin{array}{l}\text { Shaver, K. (2017) Cities turn to 'miss- } \\
\text { ing middle' housing to keep older mil- } \\
\text { lennials from leaving. }\end{array}$ & $\begin{array}{l}\text { Transportation Section of the Washington Post. The plight } \\
\text { of affordable housing in cities like Washington, DC has } \\
\text { highlighted the Missing Middle as a possible part of the } \\
\text { solution. The focus is on the older millennials that are } \\
\text { forming couples and unable to find a larger affordable place } \\
\text { for the new family. Yolanda Cole (ULI \& architect), stated } \\
\text { city residents have grown up there and not sure where to } \\
\text { go. Cities are looking at the Missing Middle as a solution. } \\
\text { Millennials prefer MMH type housing that is close to ame- } \\
\text { nities and services. The question of what price point would } \\
\text { be affordable for the market rate builders in areas with high } \\
\text { land and building costs. Developers proposed allowing two } \\
\text { times the density on the same parcel of land, smaller bed- } \\
\text { rooms, and parking under shared patios can reduce costs by } \\
\text { half. The study revealed concerns that increased density will } \\
\text { bring opposition from single-family residential areas due to } \\
\text { fear of negative impact on neighborhood, schools over- } \\
\text { crowding, high traffic, and noise. Planners, like Parolek, } \\
\text { proposed increased density in walkable neighborhoods } \\
\text { close to transit will also accommodate retiring boomers who } \\
\text { are downsizing. }\end{array}$ \\
\hline
\end{tabular}




\begin{tabular}{|l|l|}
\hline $\begin{array}{l}\text { Fry, R., Igielnik, R., \& Patten, E. (2018) } \\
\text { How Millennials today compare with } \\
\text { their grandparents. }\end{array}$ & $\begin{array}{l}\text { Ages 18-33 in 2014. Most educated generation to date (but } \\
\text { not in the STEM). More females with bachelors degrees } \\
\text { than men. More women are working at a younger age. } \\
\text { Millennials entered the workforce during tough times. Mil- } \\
\text { lennials are twice as likely not to be married. Millennials } \\
\text { are more likely to look for diversity, proximity to friends' } \\
\text { homes and amenities. }\end{array}$ \\
\hline $\begin{array}{l}\text { Sisson, P. (2016) Millennials look to } \\
\text { the suburbs, not cities, for first homes. }\end{array}$ & $\begin{array}{l}\text { Profile on millennials: Denver developer Kyle Zeppelin, } \\
\text { developers and consumers are not aligned. Developers are } \\
\text { concerned with ROI/square footage, whereas consumers } \\
\text { (millennials) are seeking value. Small, efficient and func- } \\
\text { tional spaces with amenities to suit their lifestyles and cost } \\
\text { less than \$1,000. They seek more free time to do what they } \\
\text { want. The millennial's financial reality is due to the reces- } \\
\text { sion, high student debt, difficult job market. Low homeown- } \\
\text { ership is due to high real estate prices and above. }\end{array}$ \\
$\begin{array}{l}\text { The survey revealed 79\% of millennials want to buy a home } \\
\text { but cannot afford it. This period is the lowest level of home- } \\
\text { Woo, A. (2016) The affordability crisis: } \\
\text { What happens when Millennials can't } \\
\text { afford to buy homes? } \\
\text { millennials. The low homeownership was attributed to high } \\
\text { rents, student loans, postponed marriages. Millennials sur- } \\
\text { veyed planned on home-ownership for 3-4 years. Housing } \\
\text { affordability was the biggest problem (77\%). Woo suggested } \\
\text { millennials may take up to ten years or more to save for a } \\
\text { down payment. }\end{array}$ \\
\hline
\end{tabular}

2017).

\section{Density: Common Theme of Neighbor- hood Opposition and Lack of Develop- er Interest}

According to Koebel et al. (2004), in their report to the National Association of Realtors, there is insufficient land that is zoned dense for affordable housing (MMH types). Common themes in the literature include neighborhood opposition, a lack of developer interest in building these units, lack of financing available, and high costs (Burks, 2017; Doherty, 2017; Koebel et al., 2004; Kolson, 2016; McKinney, 2016; Mich, 2017; Shaver, 2017).

The neighborhoods' opposition is due to fear of declining property values. They associat high-density housing with poverty, tenement housing, and poorly managed properties (Koebel et al., 2004). Mich (2017) suggested developing protection mechanisms and assurances for maintaining the neighborhood character in the development of "Missing Middle Housing."

\section{Affordability and Walkability}

Almost 13 years later, affordability and walkability factors continue to emerge in the media, practitioners' magazines and literature (Burks, 2017; Doherty, 2017; Koebel et al., 2004; Kolson, 2016; McKinney, 2016; Mich, 2017; Shaver, 2017). In Kolson's (2016) article, Parolek suggested increased den- sity, efficiency in space, shared spaces and adjacency to transit will counter the relative cost of the housing due to the high cost of land and construction. Walkability and adjacency to transit are significant in offsetting the costs of housing (Parolek, 2016). Residents and employees carry an added cost burden in places like the Tampa Bay area, which does not have an efficient regional transit system. In addition to the housing costs, these deficiencies in transit can result in additional cost burdens of $\$ 9,000$ per year to an employee to pay for and maintain a car with insurance (AAA, 2018; Site Selection Group, 2017; United Way Suncoast, 2017).

\section{Preserving the Existing Small and Me- dium Multifamily Housing (SMMH)}

One study conducted by Enterprise Community Partners in partnership with the Bedrosian Center on Governance at the University of Southern California (USC), focused on preserving and the allowance of new Small and Medium Multifamily Housing (SMMH) to increase/maintain the supply of these housing types in the urban core. These are buildings that are 2-49 units in size (Mattson-Teig, 2017). In the 70s and 80s, these units accounted for more than $25 \%$ of all units in the U.S. However, since the 90 s, they only represent $15 \%$ of new construction because of the low return on investment for developers (Mattson-Teig, 2017). The report called for policymakers to support the creation of financial tools to preserve existing units and eliminate the barriers to 
Table 5: Barriers to MMH Types

\begin{tabular}{|c|c|}
\hline Source & Contribution/Findings \\
\hline $\begin{array}{l}\text { Doherty, C. (2017) The great Ameri- } \\
\text { can single-family home problem. }\end{array}$ & $\begin{array}{l}\text { The article in the Economy Section of the NY Times relates } \\
\text { the plight of affordable housing in Berkeley, California. Saw } \\
\text { higher density in SF neighborhoods as a way to increase the } \\
\text { housing supply. Pros: Neighborhood opposition to density } \\
\text { and "missing middle" housing types as a possible solution } \\
\text { for starter homes for young families. The article provided } \\
\text { examples of neighborhood barriers to development with } \\
\text { graphic illustrations of the potential of three houses on sin- } \\
\text { gle-family lots. Doherty cited opposition and impediments } \\
\text { as a trend for the rest of the nation. }\end{array}$ \\
\hline $\begin{array}{l}\text { Kolson, A. H. (2016) Will U.S. cities } \\
\text { design their way out of the affordable } \\
\text { housing crisis? }\end{array}$ & $\begin{array}{l}\text { - Examples of development (Washington. DC) barriers } \\
\text { include up-zoning, opposition from residents, outmoded } \\
\text { land use, and zoning regulations. The article questioned its } \\
\text { affordability. Parolek claimed affordable as based on the de- } \\
\text { sign, due to efficiency in space, shared spaces, and proximity } \\
\text { to public transit and amenities. }\end{array}$ \\
\hline $\begin{array}{l}\text { Mattson-Teig, B. (2017) Why aren't } \\
\text { more small apartment projects built? } \\
\text { An, B., Bostic, R. W., Jakabovics, A., } \\
\text { Orlando, A., \& Rodnyansky, S. (2015) } \\
\text { Small and medium multifamily hous- } \\
\text { ing units: Affordability, distribution, } \\
\text { and trends. }\end{array}$ & $\begin{array}{l}\text { Article based on a report by Enterprise Community Partners } \\
\text { and Bedrosian Center on Governance at the University of } \\
\text { Southern California, focuses on the (2-49 units) Small and } \\
\text { Medium Multifamily Housing. (SMMF). The report called } \\
\text { for policymakers to support the preservation of existing units } \\
\text { by developing financial tools and eliminate barriers to build } \\
\text { new ones. The SMMF units accounted for more than } 25 \% \\
\text { of all units in the } 70 \text { s \& } 80 \text { s; but since the } 90 \text { s, they repre- } \\
\text { sent only } 15 \% \text { of new construction. The development is less } \\
\text { economical for a developer as the work is the same for an } \\
\text { SMMF as opposed to a more extensive development with } \\
\text { lower profit margin rates. Prices are based on construction } \\
\text { and the cost of land. The assumption is the elimination of } \\
\text { regulatory barriers could produce lower rents. }\end{array}$ \\
\hline $\begin{array}{l}\text { Mich, L. A. (2017) The missing mid- } \\
\text { dle: Understanding low-rise, moder- } \\
\text { ate-density housing in Greater Boston. }\end{array}$ & $\begin{array}{l}\text { - June 2017, Mich's thesis on "The Missing Middle" defines } \\
\text { the Missing Middle by housing types and characteristics: 1) } \\
\text { Location and amount of MMH types in the Greater Boston } \\
\text { area, 2) Reasons for its decline, and 3) The barriers to the } \\
\text { development of the Missing Middle Housing. The findings } \\
\text { state: The MMH types were originally concentrated in the } \\
\text { urban core. Now suburban areas are experiencing "in- } \\
\text { creased interest" (p. 1). New construction in suburbia, did } \\
\text { not meet walkability and affordability claims. (why?) } \\
\text { Barriers included: Permitting and Land Use and Zoning re- } \\
\text { strictions to density, wealthy residents' opposition to growth } \\
\text { /density. Findings relaxation of the zoning regulations and } \\
\text { protections for neighborhood character in the development } \\
\text { of "Missing Middle" (p. 1). Proponents claim of financing } \\
\text { restrictions and developer's hesitancy to pursue this type of } \\
\text { market. Suggests, if the developers can build higher densi- } \\
\text { ties on the same single-family site, it becomes more attrac- } \\
\text { tive to pursue such developments. The goals of the MMH } \\
\text { types, of affordability, walkability and improved social } \\
\text { connections are dependent on placement to take advantage } \\
\text { of existing public infrastructure, promote connected streets- } \\
\text { capes and provide access to open spaces and the mixed-used } \\
\text { amenities }\end{array}$ \\
\hline
\end{tabular}


Table 6: The Tampa Bay Area: Missing Middle Housing Initiatives

\begin{tabular}{|c|c|}
\hline Source & Contribution/Findings \\
\hline $\begin{array}{l}\text { Burks, B. (2017) Finding the missing } \\
\text { middle - an opportunity to complete } \\
\text { the spectrum of housing options in } \\
\text { Tampa Bay. }\end{array}$ & $\begin{array}{l}\text { A Case for MMH types in Tampa Bay, Pinellas County. A } \\
\text { historical view of the development types in the area. Denser } \\
\text { communities such as Tampa - Ybor City and in Pinellas } \\
\text { County- Dunedin, Gulfport, St Petersburg, Clearwater, and } \\
\text { Largo. Three cases: 1) Developer specializing in redevel- } \\
\text { oping historic "casitas" in Ybor City, Developer Michael } \\
\text { Mincberg; 2) John Bews inspired by Ybor, City Hayes Vil- } \\
\text { lage in Oldsmar (walkable community) and build small cot- } \\
\text { tages, lower costs to build with low maintenance, making } \\
\text { it affordable; } 3 \text { ) Glencairn Cottage Court in Dunedin. Built } \\
\text { to the need for the residents to be part of the community. } \\
\text { Developer Carl Krave (Pocket Neighborhood Inc.). This de- } \\
\text { velopment is characterized by common spaces, courtyards, } \\
\text { and is walking distance to downtown Dunedin. Krave built } \\
\text { through the } 2008 \text { recession, due to demand. The article cited } \\
\text { neighborhood resistance and developer financing as barriers } \\
\text { to the housing types. }\end{array}$ \\
\hline
\end{tabular}

produce new ones (Mattson-Teig, 2017). This study may be useful for the older core areas in Tampa Bay to retain and expand this type of development.

Currently, three developers in the Tampa Bay area have used the MMH type housing idea. Michael Mincberg, Sight Real Estate, rehabilitates the historic Ybor "casitas" (Figure 3). These are one-room wide, narrow, cigar worker homes that were built in the $19^{\text {th }}$ and $20^{\text {th }}$ century near the cigar factories in historic Ybor City, Tampa (Forward Pinellas, 2017). John Bews, who was inspired by the homes in Ybor City, developed Hayes Park Village, a detached skinny home development in Oldsmar. Carl Crave developed Glencairn Cottage Court a bungalow courtyard and detached, skinny, single-family home development in Dunedin, FL (Figure 4).

These three areas demonstrate MMH types in different ways. The Ybor Casita is part of the fabric of a walkable old city that has declined and then undergone revitalization efforts. Glencairn Cottage Court is a small new development close to downtown Dunedin. It is accessible to restaurants, shopping, and other services. The shared courtyard gardens and other amenities are exclusive to the development. Hayes Park Village of Oldsmar, FL, is a new development in a suburban area. It is accessible to shopping, a school, and a neighborhood park. Both new developments required special support from policymakers with the planning and permitting processes.

\section{The Type of Housing and Neighborhood Design That Matters}

Decades of research on traditional neighborhoods, suburban neighborhoods, and the effects of urban sprawl have demonstrated the benefits of tradition- al neighborhoods. That is the benefits of walkability, community, the density for public transit, accessibility to services and amenities as well as the environmental and health benefits derived from walkability, community and less auto dependency in the traditional neighborhoods (Bach et al., 2007; Leyden, 2003). These benefits were gained from the way neighborhoods were designed and built. More specifically, derived from the layout of the streets and the houses as well as their proximity to the workplace and transit (Bach et al., 2007; Leyden, 2003). In spite of these benefits, there are barriers to the housing types in urban core neighborhoods.

\section{Choices for the Planning Profession}

Though MMH types existed in older neighborhoods for decades, Parolek's (n.d.) proposal to reintroduce MMH types in older walkable neighborhoods to help meet the demand is not readily accepted by the residents. The regulatory barriers to reintroduce MMH types in the neighborhoods, as well as opposition by the neighborhoods (Shaver, 2017) and a lack of interest by developers to construct MMH types in these neighborhoods, are considered the major factors in the limited supply. Though these barriers exist, and there is a demand for the product, planning practitioners may choose not to pursue $\mathrm{MMH}$ types in the urban core. This is due to the perceived low return on investment of their time and resources because of the political fallout that may occur from the neighborhoods that oppose MMH types.

However, with increased density, reduced off-street parking requirements, and incentives, projects can be more profitable for developers. But this may not be enough to get the developers to work in those areas. To minimize neighborhood fears of declining property values, poor quality of housing, and the nega- 
tive perceptions of the potential residents, planning practitioners may seek ways to educate residents to overcome the fears and misperceptions. They may also continue to work on the regulatory and permitting barriers to facilitate the development. Any or all of these actions will provide incremental increases of $\mathrm{MMH}$ in walkable neighborhoods.

\section{Conclusions}

Many factors affect the supply of affordable, low- to mid-rise, housing types in walkable urban areas. The missing middle housing type (MMH) is a possible solution to fit the needs of various demographic and socioeconomic groups, particularly, millennials and baby boomers. Planning practitioners are investigating $\mathrm{MMH}$ types as one way to help improve the housing supply in urban core areas (Burks, 2017). Overcoming the challenges of land use and zoning restrictions, neighborhood opposition, lack of developer interest in building these units, lack of financing, limited land available, and construction costs will help increase the supply of MMH types housing. To help counter the high costs of land and construction and improve the supply of MMH types, for-profit developers suggested some solutions to earn a higher ROI on the project and make MMH types affordable to the consumer. These suggestions included: doubling the density allowance of units on the same single-family site in certain areas; making smaller bedrooms and more efficient spaces such as shared patios; and relaxing the off-street park- ing requirements. The Bedrosian Center suggested supporting the development of financial tools for preserving existing small and medium multifamily housing (SMMH, 2-49 units), and reducing the barriers to producing new ones as another way to boost supply (Mattson-Teig, 2017). Though this research is on increasing the amount of MMH types, accessibility to transit is a major factor in balancing the overall affordability of MMH types (Kolson, 2016). Kitamura et al. (1997) demonstrated that automobile ownership is related to residential density, and residential density is related to public transit. A lack of an efficient public transit system (as in the Tampa Bay area), exacerbates the affordability issues where employees must commute distances to work, (United Way Suncoast, 2017). In their research to investigate whether new housing supply can increase housing affordability, Anenberg and Kung (2018) demonstrated that rent is more closely related to the amenities in a neighborhood.

Future work with developers, planning practitioners, interest groups, lenders, and transportation planners to investigate the feasibility of overcoming the challenges and increasing the supply of $\mathrm{MMH}$ in the lo$\mathrm{cal}$ area is necessary. Figure 4 is a graphic representation of the factors that affect the amount of MMH types in Walkable Urban Core Neighborhoods and offers potential solutions to overcome the challenges of low supply of MMH types.

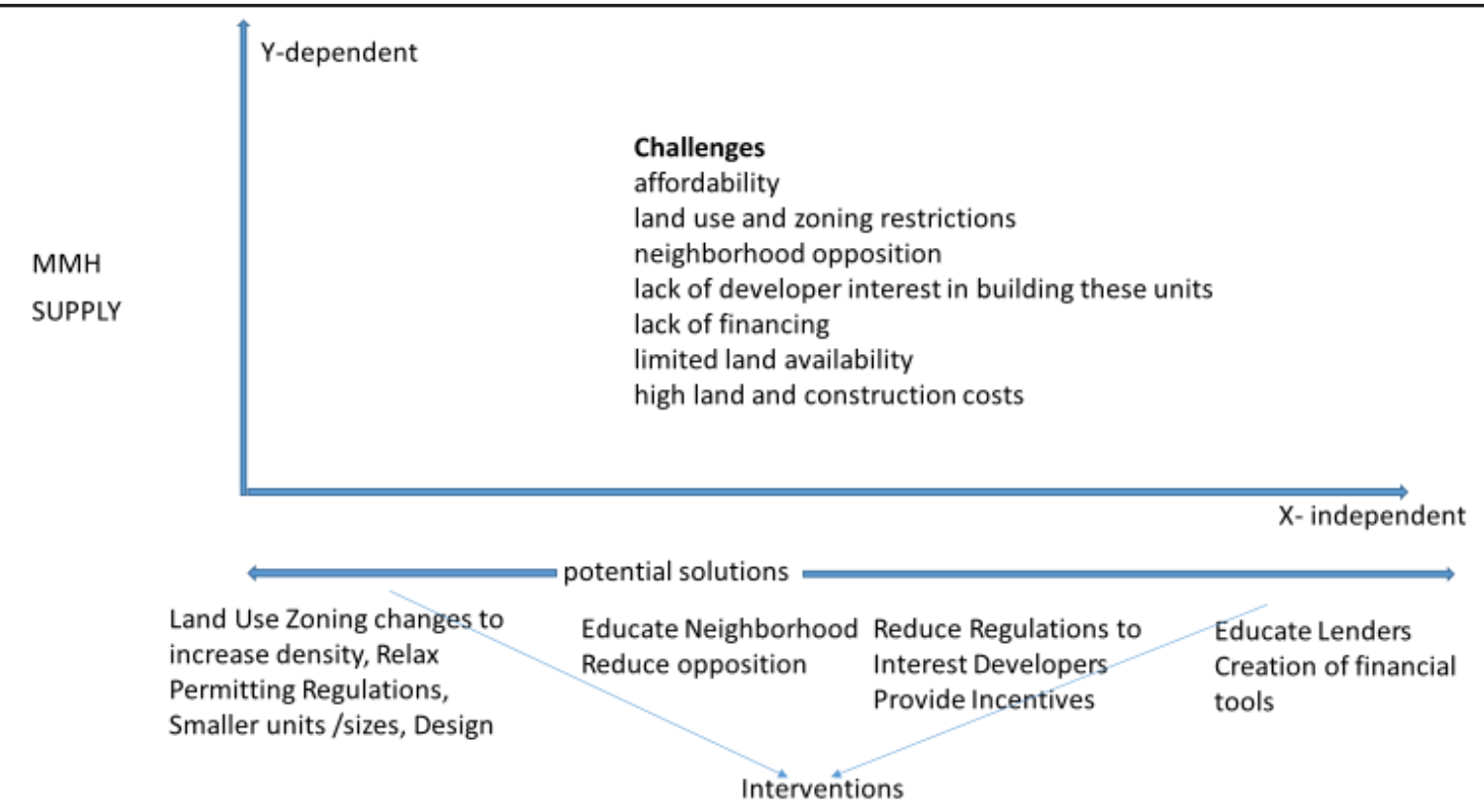

Figure 4. A graphic representation of the factors that affect the supply of MMH types in Walkable Urban Core Neighborhoods with potential solutions to overcome the challenges of low supply of MMH types. 


\section{References}

AAA. (2018). Your driving costs. American Automobile Association, September 13, 2018. Retrieved from https://newsroom.aaa.com/auto/ your-driving-costs/.

Abrahms, S. (2016). 5 Questions about the 'Missing middle housing. AARP Livable Communities, Housing, June. Retrieved from https://www.aarp. org/livable-communities/housing/info-2016/ missing-middle-housing-daniel-parolek.html.

An, B., Bostic, R. W., Jakabovics, A., Orlando, A., \& Rodnyansky, S. (2015). Small and medium multifamily housing units: Affordability, distribution, and trends. November 3, 2015. Available at SSRN: https://ssrn.com/abstract=2938809 or http://dx. doi.org/10.2139/ssrn.2938809

Anenberg, E., \& Kung, E. (2018). Can more housing supply solve the affordability crisis? Evidence from a neighborhood choice model. Regional Science and Urban Economics, [Online]. https://doi. org/10.1016/j.regsciurbeco.2018.04.012

Bach, A., Gupta, P. K., Haughey, R., Kelly, G., Pawlukiewicz, M., \& Pitchford, M. (2007). Ten principles for developing affordable housing. Washington, DC: ULI-the Urban Land Institute. Retrieved from http://uli.org/wp-content/uploads/2012/07/TP_AffordableHousing.ashx_.pdf.

Bergdoll, J. R., \& Williams, R. W. (1990). Density perception on residential streets. Berkeley Planning Journal, 5(1). https://escholarship.org/uc/ item/7wb3g30c

Burks, B. (2017). Finding the missing middle - an opportunity to complete the spectrum of housing options in Tampa Bay. Forward Pinellas, December 13, 2017. Retrieved from http://forwardpinellas.org/blog/finding-missing-middle-opportunity-complete-spectrum-housing-options-Tampa-bay/.

Cervero, R. (1996). Traditional neighborhoods and commuting in the San Francisco Bay Area. Transportation, 23(4), 373-394. https://doi.org/10.1007/ BF00223062

CNU. (2015). New online resource to meet demand for walkable communities. Public Square, CNU Journal. Retrieved from: https://www.planning. org/events/eventsingle/9122328/.

CNU. (2018). What is new urbanism? Congress of New Urbanism, Washington, DC. Retrieved from https://www.cnu.org/resources/what-new-urbanism.

Demographia. (2016). 13th Annual international housing affordability survey: 2017 rating middle income housing affordability. Retrieved from http://www.demographia.com/dhi2017.pdf.
Doherty, C. (2017). The great American single-family home problem: The New York Times, December 1, 2017. Retrieved from https://www.nytimes. com/2017/12/01/business/economy/single-family-home.html.

Forward Pinellas. (2017). Planning and placemaking grant program: Retrieved from http://forwardpinellas.org/projects/planning-placemaking-grant-program/.

Fry, R. (2018). Millennials projected to overtake Baby Boomers as America's largest generation. Pew Research Center, March 1, 2018. Retrieved from http://www.pewresearch.org/ fact-tank/2018/03/01/millennials-overtake-baby-boomers/.

Fry, R., Igielnik, R., \& Patten, E. (2018). How Millennials today compare with their grandparents 50 years ago. Pew Research Center, March 16, 2018. Retrieved from http://www.pewresearch. org/fact-tank/2018/03/16/how-millennials-compare-with-their-grandparents/.

Greenwald, M., \& Boarnet, M. (2001). Built environment as determinant of walking behavior: Analyzing nonwork pedestrian travel in Portland, Oregon. Transportation Research Record: Journal of the Transportation Research Board(1780), 33-42. https://doi.org/10.3141/1780-05

Kitamura, R., Mokhtarian, P. L., \& Laidet, L. (1997). A micro-analysis of land use and travel in five neighborhoods in the San Francisco Bay Area. Transportation, 24(2), 125-158. https://doi. org/10.1023/A:1017959825565

Koebel, C. T., Lang, R. E., \& Danielsen, K. A. (2004). Community acceptance of affordable housing: National Association of Realtors; Virginia Tech Center for Housing Research and Metropolitan Institute. https://digitalscholarship.unlv.edu/sea_ fac_articles/350.

Kolson, A. H. (2016). Will U.S. cities design their way out of the affordable housing crisis? Next City, January 18, 2016. Retrieved from https://nextcity. org/features/view/cities-affordable-housing-design-solution-missing-middle.

Leyden, K. M. (2003). Social capital and the built environment: The importance of walkable neighborhoods. American Journal of Public Health, 93(9), 1546-1551. doi:10.2105/AJPH.93.9.1546

Lidwell, W., Holden, K., \& Butler, J. (2010). Universal principles of design: 125 ways to enhance usability, influence perception, increase appeal, make better design decisions, and teach through design (revised and updated ed.). Rockport Publishers.

Lovejoy, K., Handy, S., \& Mokhtarian, P. (2010). Neighborhood satisfaction in suburban versus traditional environments: An evaluation of 
contributing characteristics in eight California neighborhoods. Landscape and Urban Planning, 97(1), 37-48. https://doi.org/10.1016/j.landurbplan.2010.04.010

Lucy, W. H., \& Phillips, D. L. (2006). Tomorrow's cities, tomorrow's suburbs. Chicago, IL: American Planning Association.

Mattson-Teig, B. (2017). Why aren't more small apartment projects built? Urban Land, April 14, 2017. Retrieved from https://urbanland. uli.org/planning-design/isnt-america-building-small-apartments/.

McKinney, M. (2016). A dream deferred? Utilizing the limited-equity housing cooperative model as a solution to Atlanta's affordable housing issue. An option paper submitted in partial fulfillment of the requirements for the degree of Master of City and Regional Planning, Georgia Institute of Technology. Retrieved from https://smartech.gatech. edu/handle/1853/56502.

Mich, L. A. (2017). The missing middle: Understanding low-rise, moderate-density housing in Greater Boston. Dissertation, Massachusetts Institute of Technology. Retrieved from http://hdl.handle. net/1721.1/111424.

Myers, D., \& Ryu, S. (2008). Aging baby boomers and the generational housing bubble: Foresight and mitigation of an epic transition. Journal of the American Planning Association, 74(1), 17-33. https://doi.org/10.1080/01944360701802006

NAR. (2018). Research and statistics. National Association of Realtors, July 2018. Retrieved from https://www.nar.realtor/research-and-statistics.

Opticos Design Inc. (2018). Missing middle: Responding to the demand for walkable urban living. Retrieved from http://missingmiddlehousing.com/contact/.

Parolek, D. (2015). 21st century zoning: Responding to the demand for a walkable urban living. Phoenix, AZ. ULI/Reinventing Phoenix. Available from http://siz45zccow2xygm413e57r11-wpengine. netdna-ssl.com/wp-content/uploads/ sites/8/2012/03/050515_ULIPHoenix_DParolek_Form-BasedCodesWalkableUrbanism_reduced.pdf.

Parolek, D. (2016). Missing middle housing: Supplying diverse housing options along a spectrum of affordability. Journal of Case Study Research: A Publication of the Center for California Real Estate, 1(1), 32-35.

Parolek, D. (n.d.). Missing middle housing: Responding to the demand for walkable urban living: Opticos Design, Inc. Retrieved from http:// missingmiddlehousing.com/dev/wp-content/
uploads/2015/04/Missing-Middle-Housing-Responding-to-the-Demand-for-Walkable-UrbanLiving-by-Daniel-Parolek.pdf.

Pew Research Center. (2015). The whys and hows of generations research. September 3, 2015. Retrieved from http://www.people-press. org/2015/09/03/the-whys-and-hows-of-generations-research/.

Shaver, K. (2017). Cities turn to 'missing middle' housing to keep older millennials from leaving The Washington Post, December 9, 2017. Retrieved from https://www.washingtonpost. com/local/trafficandcommuting/cities-turn-tomissing-middle-housing-to-keep-older-millennials-from-leaving/2017/12/09/3a129bc8d 54a-11 e 7-95bf-df7 c 19270879 _story. html?utm_term $=.28 \mathrm{ba} 04 \mathrm{~b} 26 \mathrm{~b} 9 \mathrm{c}$.

Sisson, P. (2016). Millennials look to the suburbs, not cities, for first homes. Curbed.com, June 21, 2016. Retrieved from https://www.curbed. com/2016/6/21/11956516/millennial-first-timehome-trends-suburbs.

Site Selection Group. (2017). Comprehensive regional workforce assessment. Strategic Location Solutions, Updated Summary Report, November 28, 2017. Retrieved from https://c.ymcdn.com/sites/ www.pced.org/resource/collection/492CC230A42B-45A1-8A2B-A2E634264489/ComprehensiveRegionalWorkforceAssessmentSSG.pdf.

Tiesdell, S. (2004). Integrating affordable housing within market-rate developments: The design dimension. Environment and Planning B: Planning and Design, 31(2), 195-212. https://doi. org/10.1068/b2998

United Way Suncoast. (2017). ALICE Report, 2017. Retrieved from https://unitedwaysuncoast.org/ what-we-do/alice-suncoast-2017/.

Vision 2020 Delegates. (2002). St. Pete Vision 2020: The past, present \& future of St. Petersburg. Retrieved from https://www.stpete.org/stpete/vision2020book.pdf.

Ware, C. (2012). Information visualization: Perception for design (3rd ed.). Waltham, MA: Morgan Kaufmann/Elsevier.

Wells, N. M., \& Yang, Y. (2008). Neighborhood design and walking: A quasi-experimental longitudinal study. American Journal of Preventive Medicine, 34(4), 313-319. https://doi.org/10.1016/j. amepre.2008.01.019

Woo, A. (2016). The affordability crisis: What happens when Millennials can't afford to buy homes? Apartment List, April 13, 2016. Retrieved from https://www.apartmentlist.com/rentonomics/ millennials-and-homeownership-2016/. 
Zeng, C., Liu, Y., Liu, Y., \& Qiu, L. (2014). Urban sprawl and related problems: Bibliometric analysis and refined analysis from 1991 to 2011. Chinese Geographical Science, 24(2), 245-257. https:// doi.org/10.1007/s11769-013-0619-4

\section{Review}

This article was accepted under the constructive peer review option. For futher details, see the descriptions at:

http://mumabusinessreview.org/peer-review-options/

\section{Author}

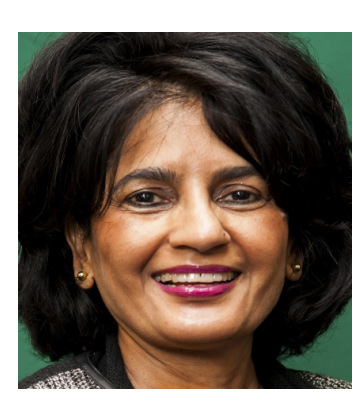

Shrimatee Ojah Maharaj has more than 25 years' experience with the city of St Petersburg in Urban Planning, neighborhood /business corridor planning and redevelopment, economic development and small business retention and expansion. Originally from Trinidad and Tobago, she recently graduated from the Muma College of Business, University of South Florida with the Doctor in Business Administration (DBA), a graduate of the University of Florida, Master's in Urban and Regional Planning (MAURP) and the Bachelor of Science, General, University of the West Indies, Trinidad. She is also a founding member on the advisory board for the Gibbs High School, BETA Program (Business Economics and Technology Academy) and on the Board of directors' member for the Pinellas Opportunity Council, a social action/anti-poverty organization.. 